\title{
Application of electrical resistivity imaging (ERI) for the assessment of peat properties: a case study of the Całowanie Fen, Central Poland
}

\author{
Sebastian Kowalczyk ${ }^{1}\left({ }^{\circ} \cdot\right.$ Kornelia Anna Żukowska $^{1} \cdot$ Maciej Jan Mendecki $^{2} \cdot$ \\ Dominik Lukasiak ${ }^{1}$
}

Received: 3 February 2017/ Accepted: 7 February 2017/Published online: 1 March 2017

(C) The Author(s) 2017. This article is published with open access at Springerlink.com

\begin{abstract}
Complex studies were carried out to recognize the fen structure and peat properties in the Całowanie Fen area, belonging to the Natura 2000 network. The studies were conducted in two study areas that differ significantly in terms of peat thickness. Electrical resistivity imaging (ERI) was used to identify the properties of the peat and its substrate, such as thickness and electrical resistivity. Comparison of the field studies with the laboratory tests has shown that the ash content rises electrical resistivity in peat. In addition, the study has shown that the application of non-invasive geophysical methods in protected areas is justified. The fen, as a medium containing mostly water, was a proper test area for the ERI measurements.
\end{abstract}

Keywords Peat $\cdot$ Electrical resistivity imaging (ERI) · Physical properties - Całowanie Fen

\section{Introduction}

Incomplete decomposition of plant debris under the influence of strong hydration results in peat formation. The process of peat accumulation is called sedentation and it is related to the deposition of the material in the place of origin (Ingram 1978). Generally, in Poland dominate shallow fens that are fed by surface water and/or groundwater. The Całowanie peatland belongs to such fens; it is also sub-classified as soligenous being fed only by the

Sebastian Kowalczyk

s.kowalczyk@uw.edu.pl

Faculty of Geology, University of Warsaw, Warsaw, Poland

2 Faculty of Earth Sciences, University of Silesia in Katowice, Sosnowiec, Poland unconfined aquifer system. Furthermore, the Całowanie Fen is located in the Vistula River Valley in close proximity to a postglacial upland and it is an interesting object of study because of its geomorphological conditions. However, the fen location within the Mazowiecki Landscape Park and its inclusion within the Natura 2000 Network forced us to use non-invasive research methods that would not affect the environment significantly. In this case, the selected geophysical methods, beside geological drillings, are an excellent tool to study areas sensitive to human interference. Variation in the physical parameters of the peat and its substrate allow to apply several geophysical methods in the investigation of the vertical succession and recognition of hydrogeological conditions. Peatlands are investigated mostly using the ground penetrating radar (GPR) method. Only a few researchers (e.g., Slater and Reeve 2002; Comas et al. 2015; Walter et al. 2016) have applied induced polarization imaging, electromagnetic terrain conductivity and electrical resistivity imaging, apart from the GPR method, as alternative tools to determine the peatland thickness.

The primary objective of the presented investigations was to test the potential of electrical resistivity imaging (ERI) to analyze the variability of peat layer thickness and estimate the physical parameters of peat. Moreover, the studies were focused on assessing the measurement and interpretation methodology of ERI in such a difficult terrain as peatlands. Our intention was also to assess the geophysical data relation to geological information obtained from the drilling such as physical properties of the peat. The studies were conducted in two areas, located within one large peatland, that differ significantly in thickness and macroscopic properties of organic soils. The paper also showed that the resistivity imaging provides valuable information about the stratigraphic contacts. The 
data obtained from the geophysical and geological studies have been correlated to provide a wider picture of sediments building the peatland and its substrate.

Peatlands are characterized by variability in thickness of the deposit on a very small area. Additionally, the legal protection which they are subject to very often hampers or precludes peat investigation using standard geological methods. Therefore, application of non-invasive geophysical methods is particularly useful in the study of peat. The resistivity imaging, inter alia, provides information about the thickness of the deposit along the test profile. They also provide information on the geological structure of the peatland substrate which is valuable data in determining the geological conditions and, moreover, in conjunction with hydrogeological studies, makes it possible to design a hydrodynamic model of the analyzed area.

Presently, the geoengineering investments are designed very often in areas where organic soils are present; therefore, the identification of the hydrogeological conditions as well as knowledge about the physical-mechanical properties of peats and its substrate are crucial issues, and the information obtained using geophysical methods can become more practical.

\section{Study area}

The Całowanie Fen, covering an area of $12 \mathrm{~km}^{2}$, is one of the largest peatlands in the Masovia region. It is located to the south-east of Warsaw and lies almost entirely within the limits of the Masovian Landscape Park (MLP). It extends in an almost $15 \mathrm{~km}$ long and $3 \mathrm{~km}$ wide belt (Fig. 1).

The fen developed in the paleochannel of the Vistula River within the lower upper terrace called the Praga terrace. Beside peatlands, the study area contains a system of dunes within organic fen deposits. The dunes originated from the accumulation of fluvial deposits such as outwashes (e.g., Góra Niedźwiedzia) or shoal islands representing mineral 'islands' within the peatland (e.g., Kobyla Góra, Góra Pękatka), which are in fact initial dunes, 2-3 m high and 20-30 m wide, with a length up to several tens of meters (Baraniecka 1982).

The peat thickness within the Całowanie Fen is variable and depends on the morphology of the mineral substrate, generally decreasing to the north; thus, the largest thicknesses around 3-4 m are noted in the southern part of the peatland. In the northern part, the peat thickness does not exceed $1.3 \mathrm{~m}$. The organic deposits are generally underlain by sand of the Vistula River lower upper terrace. Additionally, in several places the peat is underlain by gyttia or thin mud layers. The levelled surface of the peatland is
Fig. 1 Location of the study areas: a on a sketch-map of the Masovian Landscape Park; b on a fragment of the Detailed Geological Map of Poland in the scale of 1:50,000, Otwock sheet (Baraniecka 1975) and Osieck sheet (Sarnacka 1964); c, d on a fragment of a topographic map

characterized by a western dip, from $2.3 \%$ (in the south) to $4.4 \%$ o (in the north).

Two survey areas characterized by different peat thickness were selected for the geophysical study. The first was in the Kobyla Góra area (Fig. 1c) where the peat originated on a mineral island and attained a small thickness on its rim. The second was in the Gole area (Fig. 1d); this site has the largest peat thickness in the entire Całowanie Fen. Kobyla Góra represents an incipient dune characterized by the height of $2.5-3 \mathrm{~m}$ and a meridional orientation reaching a maximum length of $255 \mathrm{~m}$. The fen within the Kobyla Góra area is mostly overgrown by sedges, reeds (occurring in several places) and shrub vegetation growing along the drainage ditches. In contrast, the Gole area is flat and covered mainly by grass.

The peatland is generally supplied by groundwater from the first aquifer. Seasonal oscillations occur in the water table of the first aquifer, depending on the dominant watersoil and atmospheric conditions. Within the study areas, the depth of the water table varies from above the surface (western part of Kobyla Gora) to below the surface (Gole and the eastern part of Kobyla Góra).

\section{Methods}

\section{Geological survey}

Fieldworks, including general observations, were focused on the analysis of the geological environment of the peatland and they covered following methods: drillings to show the vertical peat succession, macroscopic descriptions with particular attention drawn on the degree of peat decomposition according to the von Post scale (von Post 1922), groundwater level measurements, grain size composition of the coarse-grained soils, and studies of the physical and chemical parameters of water.

The fieldworks methodology was focused on identifying peat properties that depend on: the botanical composition of the peat-forming areas, the degree of peat decay, and hydrogeological conditions (peatland recharge, groundwater table depth, physical and chemical properties of water).

Within the Gole study area, 13 drillings were made using the Instorf probe; 60 samples of peat were collected from all drillings. In the Kobyla Góra study area, 15 drillings were made and 16 samples of peat were collected. 

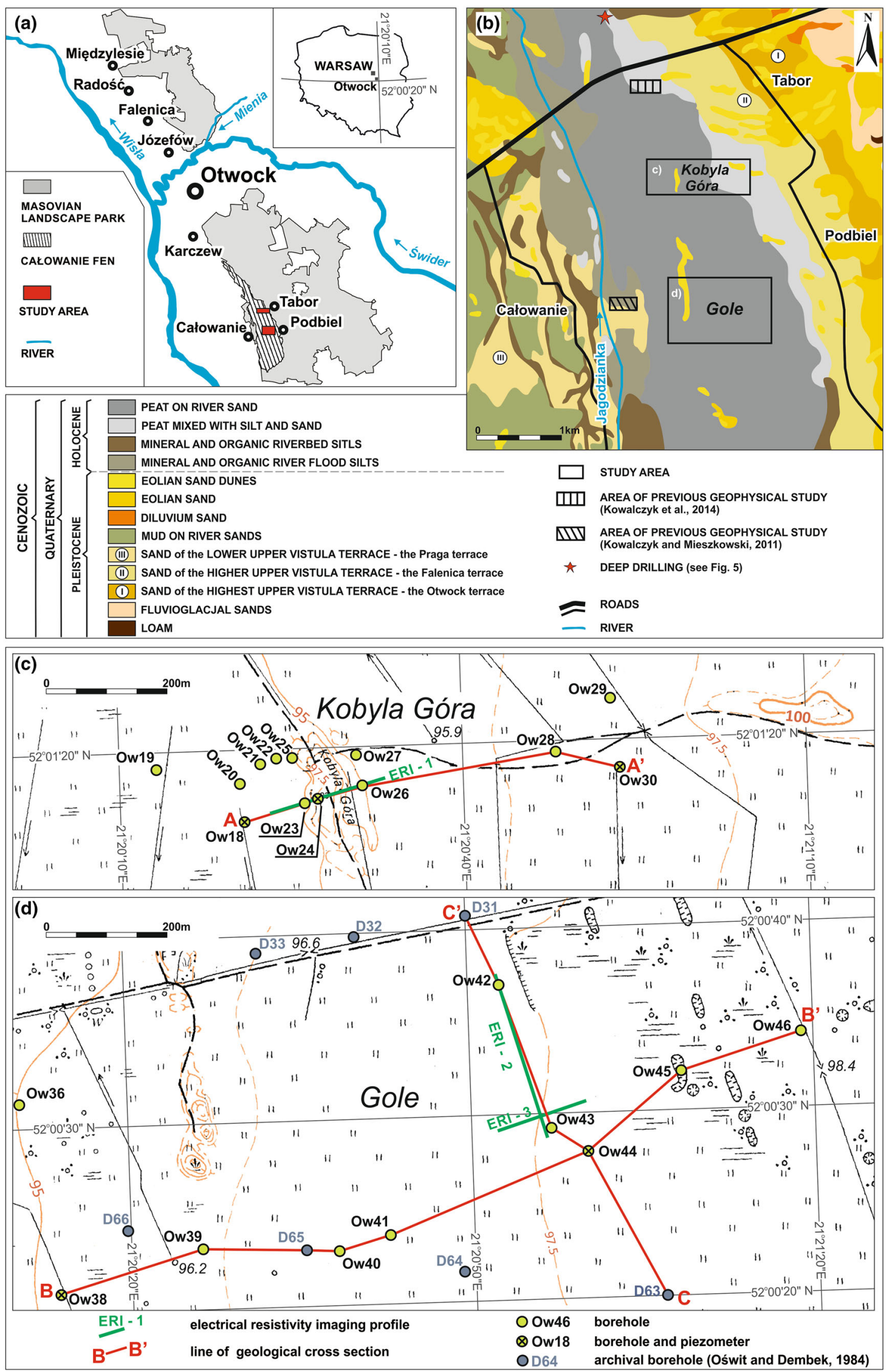
The collected samples were used for macroscopic determination of the peat type and the degree of decomposition based on the 10-point von Post scale (von Post 1922); these parameters were identified by hand squeezing the peat sample and observing the amount, color and volume of the extruded water, and the nature of plant remains in the hand. The peat samples were tested for: natural moisture content, ash content and $\mathrm{pH}$ value. The ash content value was determined by igniting the samples at $440{ }^{\circ} \mathrm{C}$ (ASTM D2974 2000; Myślińska 2001). The value of pH was tested in a suspension of peat and distilled water with a ratio of the solid phase to distilled water of 1:2.5 (Myślińska 2001). The $\mathrm{pH}$ measurements were carried out using the CX-401 multi-device connected to a $\mathrm{pH}$-metric electrode.

The five piezometers were installed within the following study areas: three Kobyla Góra and two in the Gole area (one of them (Ow44) was filtered on three depths: 1.5, 3.0 and $4.2 \mathrm{~m}$ ). Piezometers were used to measure the depth of the water table and to estimate the electrical conductivity of water (ECW), water $\mathrm{pH}$, and to collect water samples for chemical analysis.

\section{Electrical resistivity imaging}

The resistivity method is one of the oldest geophysical survey techniques (Schlumberger et al. 1933; Archie 1942; Sumner 1976; Telford et al. 1990; Loke 2011) and is commonly applied in fields such as engineering and environmental investigations (e.g., Zogała et al. 2009; Pacanowski et al. 2014; Amini and Ramazi 2016), geological (e.g., Shemang and Molwalefhe 2009; Barski and Mieszkowski 2014; Mieszkowski et al. 2014) and hydrogeological (e.g., Asfahani and Abou Zakhem 2013; Giang et al. 2013) studies. The purpose of electrical surveys is to determine the subsurface resistivity distribution by performing measurements on the ground surface. From these measurements, true resistivity can be estimated by an appropriate inversion routine. Ground resistivity is related to various geological medium and it is clearly dependent on the moisture content, water content and ways of its distribution in the medium (porosity, degree of saturation, degree of cementing, fracturing), as well as mineral composition, structure, and texture of the soil or rock. The relationships between these factors for coarse-grained soils were described by Archie (1942). Electrical properties of cohesive soils are more complex due to the amount and type of clay minerals and are related to ionic, molar and electric conductivity, as well as presence of the electric double layer in clay particles (Waxman and Smith 1968), the degree of saturation, structure, and soil consolidation (Fukue et al. 1999). By analogy, peat electrical resistivity depends on water conductivity in the peat pores, moisture content and electric conductivity of the peat matrix that depends on the organic and mineral content, mineral composition, degree of peat decomposition, structure and porosity.

Organic (peat), non-cohesive (river sands) and consolidated cohesive soils (loams and Pliocene clays) occur beneath the surface of the study. In consequence, the geology of the study area could be identified more precisely using the method of electrical resistivity imaging (ERI). Electrical resistivity imaging is also known as electrical resistivity tomography (ERT) (Loke 2011; Loke et al. 2013). The measurements were conducted using the Dipole-Dipole array with application of the Terrameter LS apparatus of the Swedish company ABEM, connected to 4 cables, each containing 21 electrodes, spaced every $2 \mathrm{~m}$. When the length of the measuring line was longer than $160 \mathrm{~m}$, the roll-along technique was applied.

Field data obtained from ERI measurements were interpreted using Res2DInv software (Loke 2001; Loke 2012; Loke and Barker 1996; Loke et al. 2003). Processing involves the inversion routine in which the most probable geo-electrical model is obtained. Raw data were converted to a Res2DInv format using the LS Terrameter Utilities Software. Later, the bad points were removed. The topography correction was included in the profile from Kobyla Góra. The best model was selected by successive calculations and subsequent comparisons (iterations) of the model and the data. The parameters of the processed data are presented in Table 1. Low values of the RMS error indicate a very good fit and high correlation between the result of apparent resistivity measurements and the estimated model of a "true" resistivity model. According to the theoretical assumptions of the ERI method, the resistivity values are assigned to an individual depth of the block centres forming a plane-parallel block grid. The inversion result can be presented as a block model scheme or an interpolated contour map with a color scale. Data interpolation allowed to obtain a quasi-continuous resistivity distribution. The geological interpretation was performed based on a block model scheme of resistivity distribution.

\section{Results}

\section{Geological survey}

In the Kobyla Góra study area, the peat thickness is up to $1.5 \mathrm{~m}$. The top of the peat deposit is dominated by a medium decomposed (H5-H6) reed peat and sedge peat. Below is situated highly decomposed (H7) reed peat. In the peat base, wooden peat characterized by a small thickness $(\sim 0.25 \mathrm{~m})$ is observed in several places (Fig. 2). The depth of the water table in the analyzed area ranges from 
Table 1 Parameters of the electrical resistivity imaging survey

\begin{tabular}{llllllll}
\hline Study area & Array & $\begin{array}{l}\text { Electrode } \\
\text { spacing } \\
(\mathrm{m})\end{array}$ & $\begin{array}{l}\text { Length of } \\
\text { profile }(\mathrm{m})\end{array}$ & $\begin{array}{l}\text { Total number } \\
\text { of data points }\end{array}$ & $\begin{array}{l}\text { Number of data } \\
\text { points after removed } \\
\text { bad points }\end{array}$ & $\begin{array}{l}\text { Minimum - maximum } \\
\text { apparent resistivity } \\
\text { values }\end{array}$ & $\begin{array}{l}\text { Iteration } \\
\text { RMS error } \\
(\%)\end{array}$ \\
\hline Kobyla Góra & $\begin{array}{c}\text { Dipole- } \\
\text { Dipole }\end{array}$ & 2.0 & 200 & 1794 & 1631 & $23 \div 13,757$ & 7 \\
Gole (S-N) & $\begin{array}{c}\text { Dipole- } \\
\text { Dipole } \\
\text { Dipole- } \\
\text { Dipole }\end{array}$ & 2.0 & 280 & 2999 & 2993 & $22 \div 103$ & 7 \\
Gole (W-E) & 2.0 & 160 & 1467 & 1432 & $28 \div 107$ & 7 \\
\hline
\end{tabular}

$0.2 \mathrm{~m}$ (measurements from 2013-10-01) below the ground surface in the eastern part (Ow30 borehole) to $0.15 \mathrm{~m}$ (2013-10-01) above the surface in the western part (Ow18 borehole). Due to the level of the groundwater table of the first aquifer and its small fluctuations, a moorsh layer is absent or insignificant in the western part of the peatland.

The southern part of the Całowanie Fen (Gole study area) is characterized by the largest thickness of the peat deposit up to the maximum value of $4.65 \mathrm{~m}$ (Ow43 borehole) and the taxonomic diversity of the peat profile is very low. The peat profile composed mainly of sedge peat is characterized by medium decomposition (H4-H5). Moreover, thin sand interbeds (about $0.05 \mathrm{~m}$ thick) were noted in several places within the sedge peat (Fig. 2). Highly decomposed (H7) moss peat is present in the base of the peat profile. Sedge-reed peat was drilled in the eastern part of the Gole study area, whereas sedge-moss peat with calcareous gyttia occurred (D63 borehole) in the southern part. In the Gole study area, the depth of the groundwater table varied from $0.22 \mathrm{~m}$ (Ow46 borehole) to $0.28 \mathrm{~m}$ (Ow44 borehole) (measured on 2013-10-01). Below the entire Całowanie Fen, the substrate consisted of mediumand fine-grained sands of the Praga terrace-the lower upper terrace of the Vistula River.

Based on the laboratory tests, domination of weakly acidic peat $(5 \leq \mathrm{pH}<7)$ was noted. The analyzed peat samples showed slight $\mathrm{pH}$ variation. Within the Gole study area, the highest $\mathrm{pH}$ was obtained for mossy peat, and the lowest - for reed peat. The $\mathrm{pH}$ of sedge peat and reed peat from Kobyla Góra was slightly higher compared to the $\mathrm{pH}$ of the same peat type in Gole (Table 2).

In the analyzed area of the Całowanie Fen, reed peat had the highest ash content in Kobyla Góra; this resulted from the mineral material blown off the sand dune. Within the Gole study area, a significant increase in the mineral content was noted (Table 2) due to the presence of sand interbeds (Fig. 2; Ow44 and Ow42 boreholes) and calcareous gyttia (Fig. 2; Ow46 borehole) in the sedge peat.

Determinations of the natural moisture content have indicated that the peat samples taken from Kobyla Góra have a significantly lower moisture content than the samples from the Gole study area (Table 2).

The collected data of electrical conductivity of water indicate significant diversity of water physical properties between these two studies areas. ECW in Kobyla Góra is more than two times lower than in the Gole area. Also, tests have shown temporal/seasonal changes of $\mathrm{pH}$ and conductivity of water (Table 3).

\section{Resistivity results on the fen}

Resistivity measurements carried out in the Kobyla Góra study area, where the peat sedented on a mineral island and its thickness ranges from 0 to $1.5 \mathrm{~m}$, allowed a generalized investigation of this peat layer. Resistivity of this layer ranges within $50-70 \Omega \mathrm{m}$, but in the nearest vicinity of the dune and on the western side of the fen the peat was characterized by higher values $(\sim 70 \Omega \mathrm{m})$. This may be caused by the higher ash content of the peat that originated from the blown-off mineral material. On the eastern side of the dune, in the direction of the main axis of the fen, the peat had a resistivity value in the range of $40-50 \Omega \mathrm{m}$ (Fig. 3).

The small thickness of peat in Kobyla Gora and the relatively large electrode spacing $(2 \mathrm{~m})$ as compared to the thickness of the peat are the reasons why the ERI studies failed to identify the vertical variation of the physical properties within the peat profile.

In Gole, the peat usually had resistivity values in the range of 30-60 $\Omega \mathrm{m}$. This area has the greatest peat thickness in the entire Całowanie Fen. A much greater thickness of peat compared to electrode spacing allowed to identify the diversity of physical properties within the peat layer both in horizontal and vertical directions. Several zones with low resistivity values $(15-30 \Omega \mathrm{m})$ were identified within the peat layer-in the $\mathrm{S}-\mathrm{N}$ cross-section between: 82 and $86 \mathrm{~m}, 202$ and $216 \mathrm{~m}$, and 230 and $232 \mathrm{~m}$ of the measurement profile, and in a $\mathrm{W}-\mathrm{E}$ cross-section between: 68 and $74 \mathrm{~m}$, and 104 and $106 \mathrm{~m}$ of the measurement profile (Fig. 4). In the $\mathrm{W}-\mathrm{E}$ cross-section, a high resistivity 

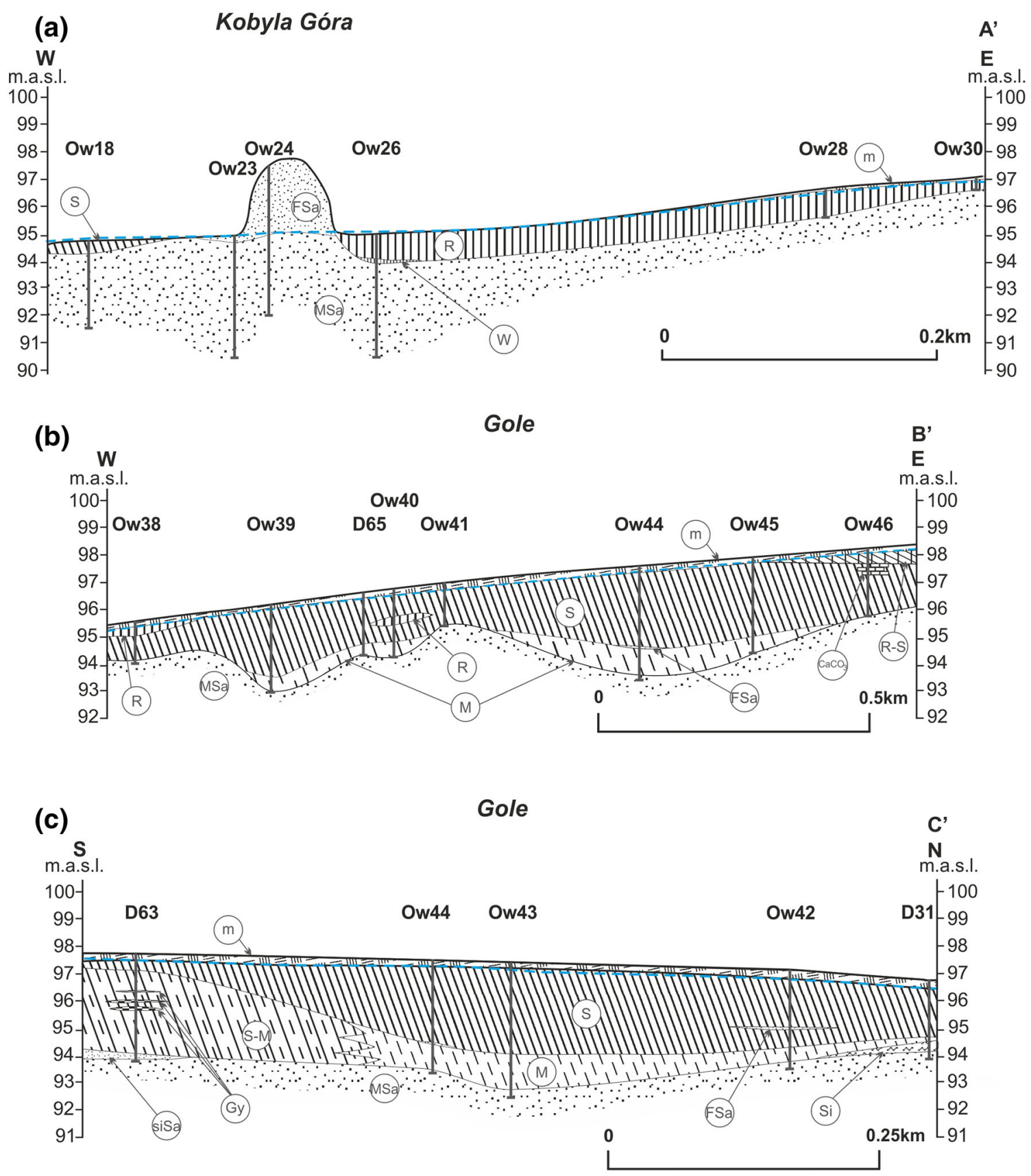

EXPLANATIONS

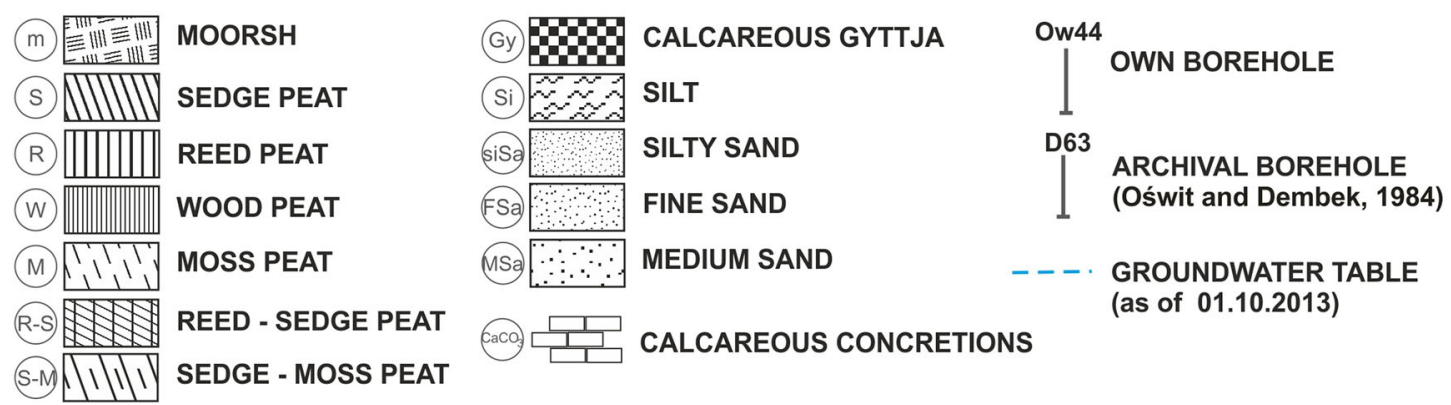

Fig. 2 Geological cross-sections (for location see Fig. 1) 
Table 2 Results of laboratory tests: natural moisture content, ash content and pH of peats for the Kobyla Góra and Gole study areas

\begin{tabular}{|c|c|c|c|c|c|}
\hline Study area & Peat type & & Natural moisture content $(\%)$ & Ash content $(\%)$ & $\mathrm{pH}(-)$ \\
\hline \multirow[t]{8}{*}{ Kobyla Góra } & \multirow[t]{4}{*}{ Reed peat } & Average value & 457.12 & 47.16 & 5.62 \\
\hline & & Range & $209.14-623.55$ & $18.22-72.96$ & $5.54-5.67$ \\
\hline & & Estimator of standard deviation & 218.91 & 21.66 & 0.05 \\
\hline & & Number of measurements & 3 & 10 & 5 \\
\hline & \multirow[t]{4}{*}{ Sedge peat } & Average value & 347.68 & 36.46 & 5.66 \\
\hline & & Range & $230.32-441.66$ & $22.71-47.07$ & $5.54-5.81$ \\
\hline & & Estimator of standard deviation & 92.27 & 12.47 & 0.11 \\
\hline & & Number of measurements & 5 & 3 & 6 \\
\hline \multirow[t]{16}{*}{ Gole } & \multirow[t]{4}{*}{ Moorsh } & Average value & 502.87 & 15.15 & 5.43 \\
\hline & & Range & $285.38-701.16$ & $8.60-26.74$ & $5.16-5.70$ \\
\hline & & Estimator of standard deviation & 131.24 & 6.95 & 0.20 \\
\hline & & Number of measurements & 10 & 10 & 9 \\
\hline & \multirow[t]{4}{*}{ Sedge peat } & Average value & 745.21 & 21.12 & 5.51 \\
\hline & & Range & $529.80-738.03$ & $7.23-80.93$ & $4.90-6.60$ \\
\hline & & Estimator of standard deviation & 134.97 & 20.06 & 0.43 \\
\hline & & Number of measurements & 33 & 33 & 36 \\
\hline & \multirow[t]{4}{*}{ Reed peat } & Average value & 684.94 & 20.52 & 5.33 \\
\hline & & Range & 499.11-906.93 & $7.74-85.46$ & $4.99-5.60$ \\
\hline & & Estimator of standard deviation & 131.80 & 22.30 & 0.20 \\
\hline & & Number of measurements & 9 & 9 & 10 \\
\hline & \multirow[t]{4}{*}{ Moss peat } & Average value & 796.66 & 40.87 & 5.57 \\
\hline & & Range & $389.78-1383.26$ & $10.62-86.99$ & $5.00-6.30$ \\
\hline & & Estimator of standard deviation & 343.27 & 26.62 & 0.46 \\
\hline & & Number of measurements & 6 & 6 & 8 \\
\hline
\end{tabular}

Table 3 Results of electrical conductivity and $\mathrm{pH}$ of water measured in the piezometers in both study areas

\begin{tabular}{|c|c|c|c|c|c|c|c|c|}
\hline \multirow[t]{2}{*}{ Study area } & \multirow[t]{2}{*}{ Borehole no. } & \multirow[t]{2}{*}{ Filter depth (m) } & \multicolumn{3}{|l|}{$\mathrm{pH}(-)$} & \multicolumn{3}{|c|}{$\mathrm{ECW}(\mu \mathrm{S} / \mathrm{cm})$} \\
\hline & & & $\begin{array}{l}01.10 . \\
2013\end{array}$ & $\begin{array}{l}08.03 . \\
2014\end{array}$ & $\begin{array}{l}12.04 . \\
2014\end{array}$ & $\begin{array}{l}01.10 . \\
2013\end{array}$ & $\begin{array}{l}08.03 . \\
2014\end{array}$ & $\begin{array}{l}12.04 \\
2014\end{array}$ \\
\hline \multirow[t]{4}{*}{ Gole } & Ow38 & 1.5 & 7.42 & 6.64 & 6.26 & 739.0 & 606.8 & 588.0 \\
\hline & Ow44 & 1.5 & 7.59 & 6.79 & 6.17 & 408.0 & 321.7 & 483.0 \\
\hline & Ow44 & 3.0 & 7.39 & 6.71 & 6.01 & 623.0 & 554.1 & 559.0 \\
\hline & Ow44 & 4.2 & 7.24 & 6.59 & 6.31 & 616.0 & 508.8 & 574.0 \\
\hline \multirow[t]{3}{*}{ Kobyla Góra } & Ow18 & 3.0 & 6.83 & 6.38 & 6.51 & 219.0 & 218.3 & 190.5 \\
\hline & Ow24 & 5.0 & 6.86 & 6.51 & 6.55 & 297.0 & 278.9 & 291.0 \\
\hline & Ow30 & 1.0 & 7.11 & 6.11 & 6.37 & 214.0 & 175.1 & 157.7 \\
\hline
\end{tabular}

anomaly was also identified between the 106 and $110 \mathrm{~m}$ directly near the surface.

Moreover, river sands and Pliocene clays were distinguished based on the obtained resistivity imaging (Figs. 3, 4). A loam layer (glacial till) probably occurs between these deposits. Lenses with higher resistivity values occurring within the river sands mainly consisted of a saturated deposit characterized by lower resistivity. These lenses are probably composed of gravel.

\section{Discussion}

The general outline of the geological structure in the study areas is known from the reports of Baraniecka $(1976,1982)$ and Sarnacka (1968, 1987). The thickness, type and physical properties of the peat from the Całowanie Fen are known from drilling surveys performed by BorówkoDłużakowa (1961) (1 borehole), Oświt and Dembek (1984) (90 boreholes), Kowalczyk et al. (2014) (7 boreholes), and 


\section{Kobyla Góra}
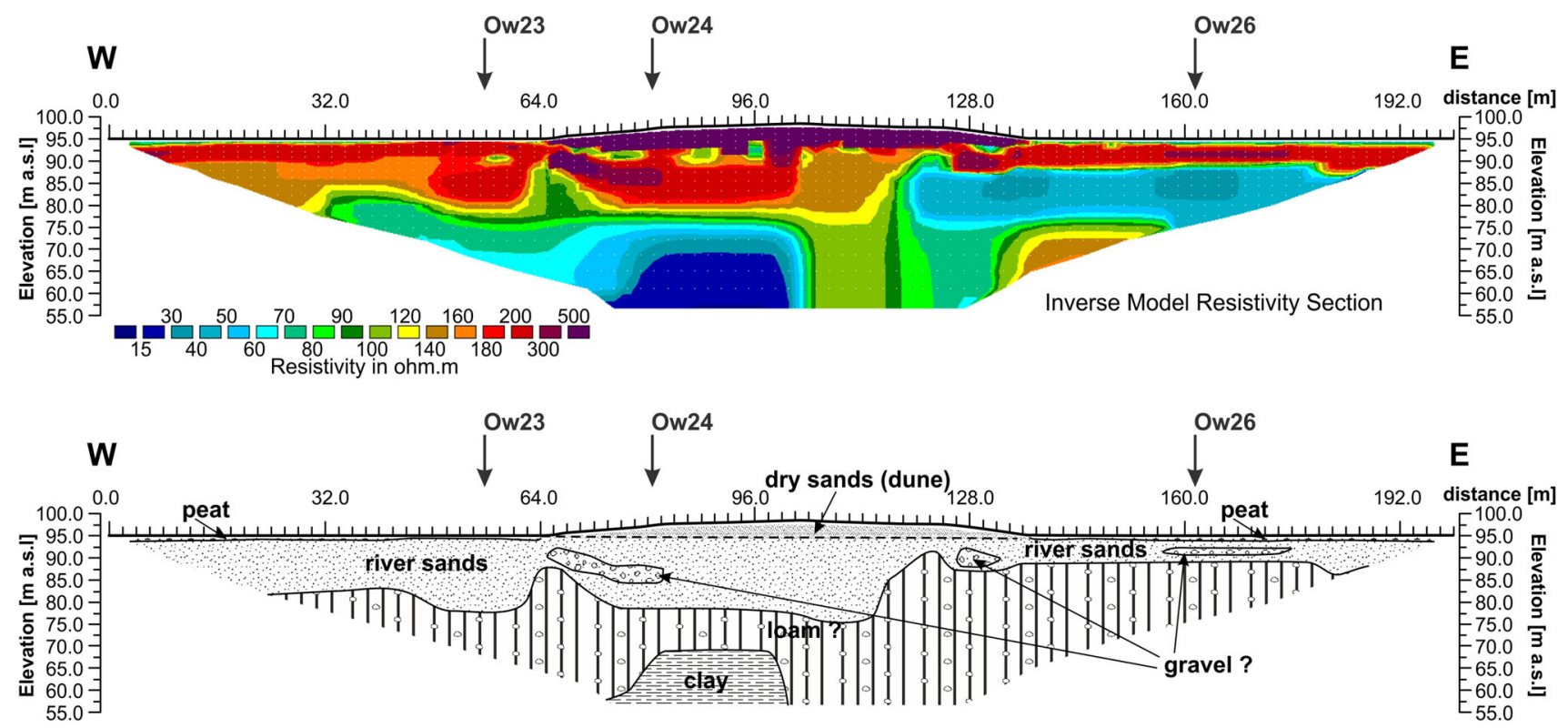

Fig. 3 Resistivity results for the Całowanie Fen in the Kobyla Góra study area: W-E pseudo cross-section

those presented in this paper. In the Całowanie Fen area, several geophysical surveys were conducted previously; they were focused on determining the basal surface of the organic deposits (Kowalczyk and Mieszkowski 2011; Kowalczyk et al. 2014). Application of geophysical methods such as ground penetrating radar, vertical electrical sounding, and refraction seismic have allowed for precise recognition of the basal surface of the organic soil and its lateral relationships with the surrounding layers (Kowalczyk and Mieszkowski 2011). However, these surveys were conducted on the margin of the Całowanie Fen and peat did not occur in the geological succession of the investigated areas; in turn, organic river flood silts covered by sands were noted. Thus, for a major part of the fen with an area of $12 \mathrm{~km}^{2}$, there were no geophysical surveys characterizing the physical properties (such as electrical resistivity) of the peat. Kowalczyk et al. (2014) showed a successful application of GPR in peatland investigations and concluded that the method provides an excellent alternative to drilling and mapping of the stratigraphy and peat thickness. This is confirmed herein by a GPR survey in the central and eastern part of the Całowanie Fen. This survey allowed to: determine the boundary between the different peat types and distinguish the boundaries within one peat type characterized by variable physical properties resulting from the degree of decomposition. However, a clear impact of the botanical composition on the value of electrical resistivity was not recognized in the fen.

As it was mentioned in the Geological survey results section, peat in the Całowanie Fen is characterized by a high taxonomic diversity and variation in the basic physical parameters such as ash content (Table 2) and degree of decomposition. The obtained values of ash content are higher than those indicated by Ilnicki (2002) as characteristic (5-20\%) of fens. A high mineral content could be also caused by a sandier basal part of the peat profile due to strong geomorphological processes occurring during peat sedentation (Domińczak and Okupny 2010; Rydelek 2013). Geological studies of peatlands indicate that peats often lie on a thin layer of organic sands of the early phase of the lacustrine sedentation (Falkowska 2001). Usually, the basal zone of peatlands is strongly silted which is connected with the fact that this zone marks the beginning of peat accumulation on the mineral substrate and peat is strongly enriched in mineral content of substrate (Rydelek 2011; Rydelek et al. 2015).

The degree of peat decomposition affects its physical properties. An increase in the degree of peat decomposition causes a decrease in porosity, which results in increase in the bulk density and reduction of matrix density as well as natural moisture content (Hobbs 1986; Myślińska 1999, 2001). Laboratory resistivity investigations of Asadi and Huat (2009) have shown that the resistivity of peat decreased with the increasing degree of decomposition and moisture content and that peat resistivity increased with increasing organic content. These laboratory tests have not been explicitly confirmed by the field surveys presented in this paper. This results probably from the spatial variability of the peatland and influence of individual factors (such as moisture content, ash 

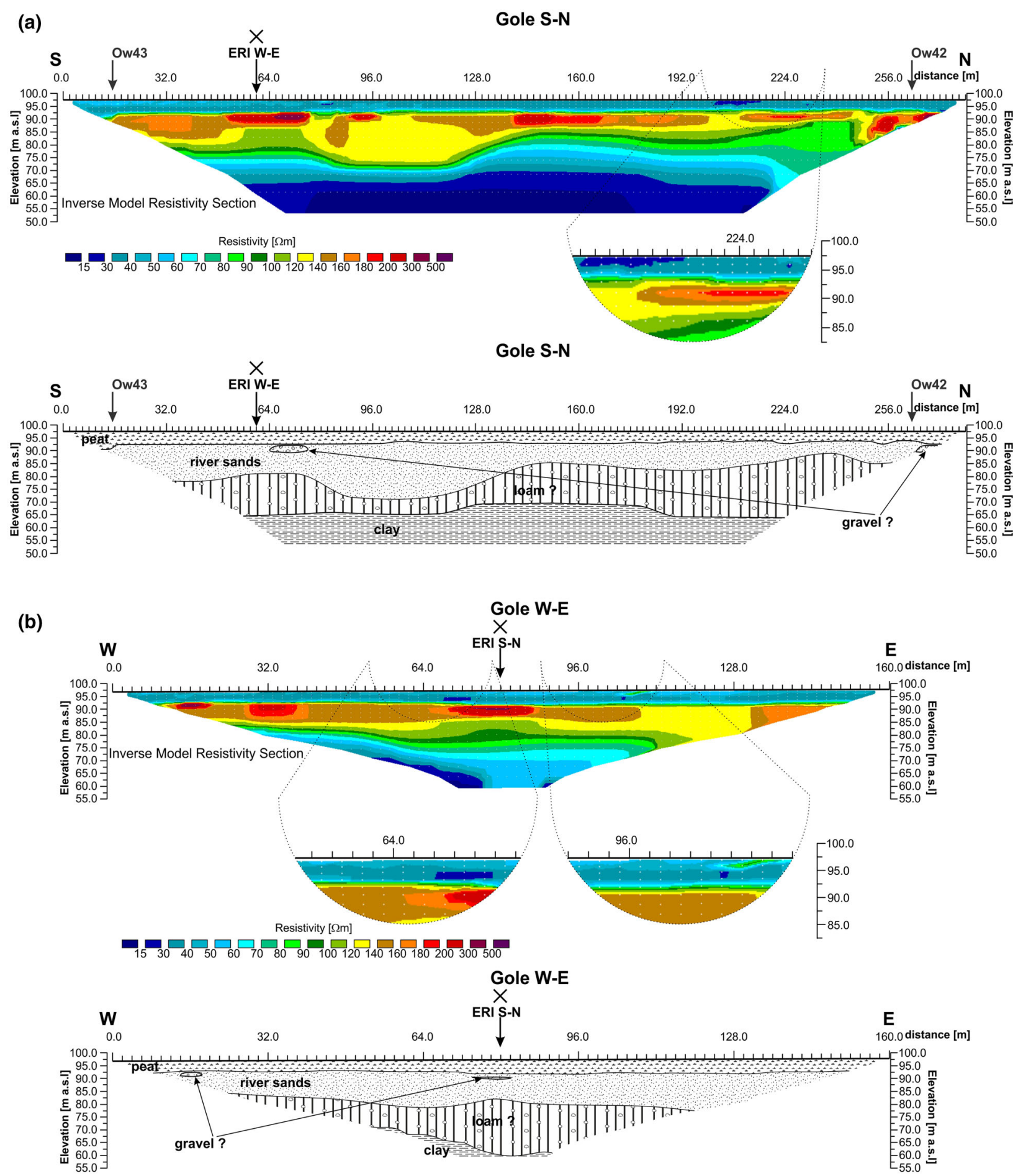

Fig. 4 Resistivity results for the Całowanie Fen in the Gole study area: a S-N pseudo cross-section; b W-E pseudo cross-section

content, degree of decomposition) on the final resistivity image obtained in the ERI survey.

The ERI method may be useful for determining the stratigraphic contact between the peat layer and the mineral substrate (Slater and Reeve 2002; Comas et al. 2015; Walter et al. 2016), which is also confirmed by this report.
The performed electrical resistivity survey proved its usefulness for mapping peat layers, regardless of their thickness. It is obvious that the resistivity imaging results are better where the peat thicknesses are larger. Moreover, differences in the physical properties within the peat layers can be also indicated. However, when the peat layer is 
characterized by a small thickness, electrode spacing must be selected carefully, so that the peat layer will not be hidden or generalized. It is commonly known that the Dipole-Dipole array does not work properly during investigation of horizontal structures. However, the application of this array has yielded good results in the researches carried out in the Caribou Bog by Comas et al. (2004). Results of electrical resistivity imaging presented in this paper, obtained with a Dipole-Dipole array, are also promising.

The ERI survey in Gole has indicated the vertical and horizontal variation of the physical properties of peat. The diversity of physical properties in vertical profile is also visible in the water samples collected from three depths several times during the year from the filtered piezometer of the OW44 drilling site. The research has shown (Table 3) that when the measurement would have been made only in April, 2014, it would be possible to conclude that water conductivity increased with depth. However, previous investigations have disrupted this trend because the measurements of the water samples from the middle depth of the filtered piezometer $(3.0 \mathrm{~m})$ had the highest conductivity values in comparison to the others. ECW spatial variability was also noticed within the Kobyla Góra study area; as manifested in higher values of water conductivity in the dune (Ow24 borehole) than in the fen (Ow18, Ow30 boreholes) (Table 3). The reasons for this phenomenon probably lie in the high sorption properties of peat. Soil colloids are electronegative; therefore, cations such as $\mathrm{Na}^{+}, \mathrm{K}^{+}, \mathrm{Ca}^{2+}$ are subjected to sorption processes. Chemical analysis of the groundwater samples in Kobyla Góra seems to confirm this observation. Plant root system assimilation of some solutes (especially during spring and summer) and, to a smaller extent, rainfall infiltration in the dune may also have an impact on the decrease of groundwater conductivity in the peatland.

The variability of the properties in the peatland can manifest itself, as in the western side of the Kobyla Góra dune, by a higher resistivity associated with the presence of blown-off mineral material. ERI method did not provide accurate information on the substrate morphology and the thickness of peat contrary to the GPR survey. Detailed information from the GPR survey (Kowalczyk et al. 2014) would be very difficult to obtain using data solely from the drillings. The potential of GPR and ERI for estimating peat thickness was confirmed by Comas et al. (2015). However, these researchers indicate the limitations of geophysical methods in determining the thickness of the peat. Therefore, the studies require refinement in other test areas to develop an appropriate, non-invasive and inexpensive methodology.

A geological interpretation of the ERI measurements is hampered by the lack of a deep borehole within the
Całowanie Fen. However, a few deep drillings were made close to the fen area. One of such deep drillings was conducted near the village of Tabor, as shown in Fig. 5. Lithological data from the drill log were helpful in the interpretation of the resistivity model and increased the confidence of the generalized interpretation of soil types based on the resistivity values. The spatial identification of the geological structure can be used in further studies on the formation of the palaeo-riverbed and referring these analyses to contemporary processes influencing the morphology of the modern Middle Vistula riverbed (Falkowski 2007a). Geomorphological features of the terrace surface may be used in the engineering-geological assessment for the correct location of regulating structures and their protection. These features can be regarded as indicative in searching for protrusions of the alluvial substrate composed of deposits resistant to erosion in river valleys of lowland areas with a postglacial relief (Falkowski 2007b).

\section{Conclusion}

Application of the ERI method allowed to obtain 2D quasicontinuous images of the geological structure, which is essential for a correct interpretation of the geological phenomena occurring currently and in the past. An example is the spatial identification of the basal surface of the river sands (Figs. 3, 4) which provides information on the surface water flow during the formation of the valley before peat sedentation. In protected areas, where low invasiveness of research methods is necessary, application of geophysical methods is the best way to obtain information about the ground variability. Not only did the presented investigations allow to obtain data on the distribution of peat and its properties but also allowed for indirect understanding of the deeper geological structure in which the discrepancy in the thickness estimation based on geophysical methods increases with the depth of the prospecting.

The most accurate method to show the spatial distribution of peat basal surface occurring below the ground surface is the GPR method. Both the GPR and ERI methods enable to obtain quasi-continuous information on the variability of the physical properties of peat.

The performed pieces of research on the Całowanie Fen demonstrate significant heterogeneity of the peat in terms of physical properties such as moisture content, ash content, degree of decomposition and electrical resistivity.

The studies presented in the paper have both a cognitive and practical aspect. Presently, engineering investments are more commonly designed in areas with organic soils. The presented distribution of resistivity in relation to the physical properties of peat may become a useful tool in the 


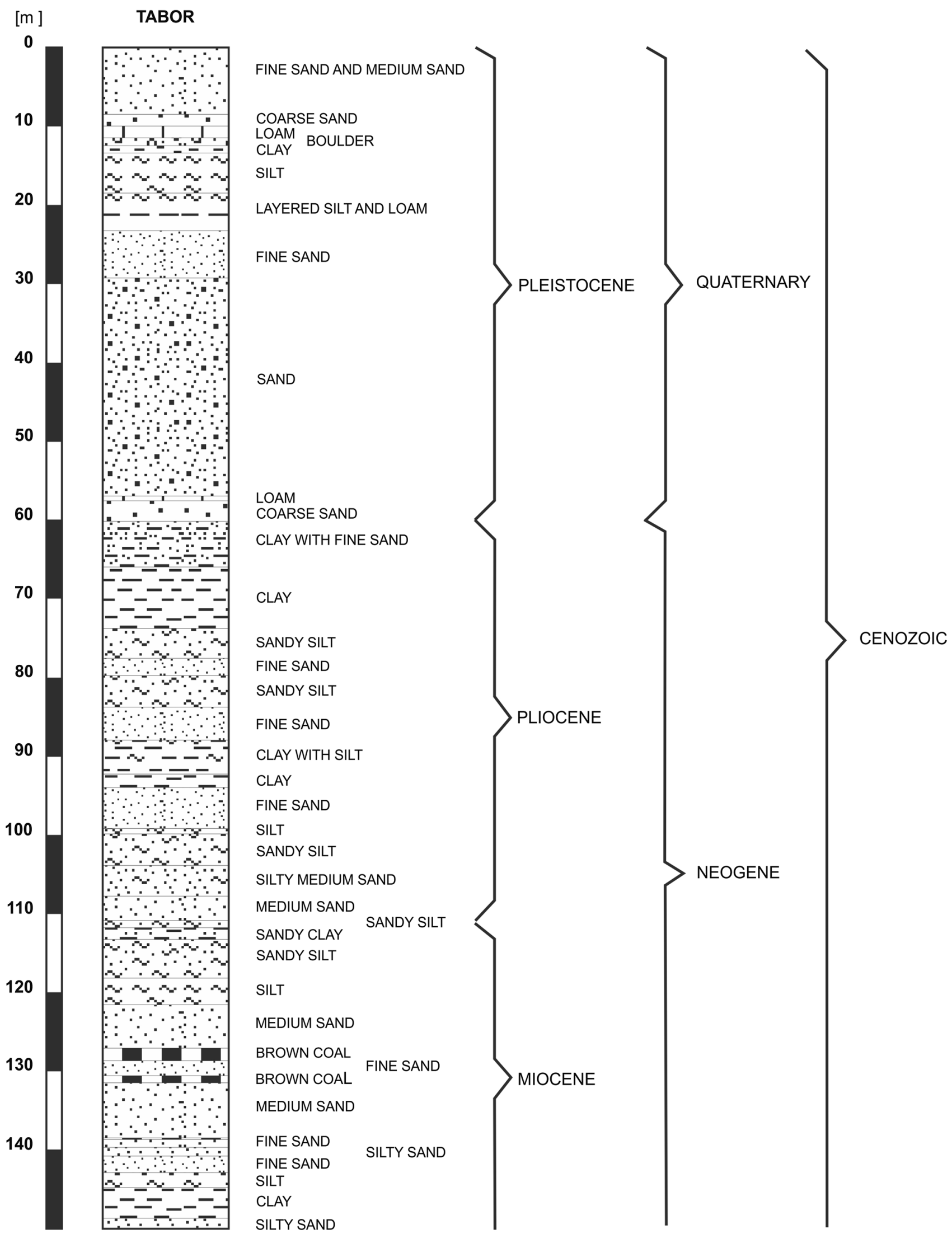

Fig. 5 Lithological column of the archival deep drilling near the area of Tabor (Baraniecka 1972) 
precise recognition of soils with low bearing capacity in other areas, which in turn may influence the geological engineering assessment of the ground.

Acknowledgements The geological and electrical resistivity imaging surveys were supported financially by the scientific projects DSM102930 and DSM-105528 of the Faculty of Geology, University of Warsaw. Terrameter LS apparatus, produced by Swedish company ABEM, was purchased as a part of the Regional Operational Program project entitled: "Modernization and equipment of the laboratories of the Faculty of Geology, University of Warsaw, to conduct research essential for Mazovia in the field of environment geoengineering STAGE I, no. RPMA.01.01.00- 14-011/10". The authors would like to thank the Reviewers as well as the Editor for their valuable comments and suggestions.

Open Access This article is distributed under the terms of the Creative Commons Attribution 4.0 International License (http://crea tivecommons.org/licenses/by/4.0/), which permits unrestricted use, distribution, and reproduction in any medium, provided you give appropriate credit to the original author(s) and the source, provide a link to the Creative Commons license, and indicate if changes were made.

\section{References}

Amini A, Ramazi H (2016) Application of electrical resistivity imaging for engineering site investigation. A case study on prospective hospital site, Varamin, Iran. Acta Geophys 64:2200-2213. doi:10.1515/acgeo-2016-0100

Archie GE (1942) The electrical resistivity $\log$ as an aid in determining some reservoir characteristics. Trans AIME 146:54-62

Asadi A, Huat BBK (2009) Electrical resistivity of tropical peat. Electron J Geotech Eng 14:1-9

Asfahani J, Abou Zakhem B (2013) Geoelectrical and hydrochemical investigations for characterizing the salt water intrusion in the Khanasser valley, northern Syria. Acta Geophys 61:422-444. doi:10.2478/s11600-012-0071-3

ASTM D2974-00 (2000) Standard test methods for moisture, ash, and organic matter of peat and other organic soils. doi:10.1520/D2974

Baraniecka MD (1972) Karta otworu wiertniczego Tabor-otwór nr 6 CAG PIG Warszawa, nr w archiwum 116889, nr CBDG 5265

Baraniecka MD (1975) Szczegółowa Mapa Geologiczna Polski w skali 1:50,000; arkusz Otwock (561). Wydawnictwa Geologiczne, Warszawa (in Polish)

Baraniecka MD (1976) Objaśnienia do Szczegółowej Mapy Geologicznej Polski w skali 1:50 000 arkusz Otwock (561). Wydawnictwa Geologiczne, p 102 (in Polish)

Baraniecka MD (1982) Dunes of the Otwock region against a geologic structure. Biuletyn Instytutu Geologicznego 337:5-32 (in Polish with English summary)

Barski M, Mieszkowski R (2014) Upper Jurassic large-scale debris flow deposits in interbiohermal basins of the sponge megafacies in Poland-new insights. Neues Jahrbuch fur Geologie und Palaontologie Abhandlungen 272:47-59. doi:10.1127/00777749/2014/0396

Borówko-Dłużakowa Z (1961) Przyczynek do znajomości torfowisk holoceńskich na tarasach Wisły pod Warszawą. Arch, Instytut Geologiczny, Warszawa (in Polish)

Comas X, Slater L, Reeve A (2004) Geophysical evidence for peat basin morphology and stratigraphic controls on vegetation observed in a Northern Peatland. J Hydrol 295:173-184
Comas X, Terry N, Slater L, Warren M, Kolka R, Kristiyono A, Sudiana N, Nurjaman D, Darusman T (2015) Imaging tropical peat lands in Indonesia using ground-penetrating radar (GPR) and electrical resistivity imaging (ERI): implications for carbon stock estimates and peat soil characterization. Biogeosciences 12:2995-3007. doi:10.5194/bg-12-2995-2015

Domińczak P, Okupny D (2010) Spatial variability of selected physicochemical properties of biogenic sediments in the Kopanicha peatland near Skierniewice. Prace Geograficzne 123:99-110 (in Polish with English summary)

Falkowska E (2001) Regularities in the occurrence of protection zones in polygenetic river valleys from the eastern part of the Polish Lowlands. Acta Geol Pol 51:163-192

Falkowski T (2007a) The application of geomorphological analysis of the Vistula River, Poland in the evaluation of the safety of regulation structures. Acta Geologica Polonica 57:377-390

Falkowski T (2007b) Geomorphologic analysis of the river terrace as an element in the geological engineering prognosis of the regulation structures safety. Geologos 11:163-172 (in Polish with English summary)

Fukue M, Minatoa T, Horibe H, Taya N (1999) The micro-structure of clay given by resistivity measurements. Eng Geol 54:43-53

Giang NV, Duan NB, Thanh L, Hida N (2013) Geophysical techniques to aquifer locating and monitoring for industrial zones in North Hanoi, Vietnam. Acta Geophys 61:1573-1597. doi:10.2478/s11600-013-0147-8

Hobbs NB (1986) Mire morphology and the properties and behaviour of some foreign peats. Q J Eng Geol Hydrogeol 19:7-80. doi:10. 1144/GSL.QJEG.1986.019.01.02

Ilnicki P (2002) Peatlands and peat, Wyd. AR, Poznań, p 606 (in Polish with English summary)

Ingram HAP (1978) Soil layers in mires: function and terminology. J Soil Sci 29:224-227

Kowalczyk S, Mieszkowski R (2011) Determination of a bottom layer of organic soil using geophysical methods at two sites on the Polish Lowland. Biuletyn Państwowego Instytutu Geologicznego 446:191-198 (in Polish with English summary)

Kowalczyk S, Łukasiak D, Żukowska K (2014) Ground penetrating radar survey in the central and eastern part of the Całowanie Fen, Central Poland. In: Proceedings of 15 th international conference on ground penetrating radar, Brussels, Belgium, June 30-July 4 2014, pp 1041-1046. doi:10.1109/ICGPR.2014.6970579

Loke MH (2001) Electrical imaging surveys for environmental and engineering studies, a practical guide to 2-D and 3-D surveys: RES2DINV manual, pp 1-65

Loke MH (2011) Electrical resistivity surveys and data interpretation. In: Gupta H (ed) Solid earth geophysics encyclopaedia, 2nd ed, "Electrical \& Electromagnetic". Springer, New York, pp 276-283

Loke MH (2012) Rapid 2-D Resistivity \& IP inversion using the leastsquares method (RES2DINV ver. 4.01 for Windows XP/Vista/7, manual), Geotomo Software, pp 1-169

Loke MH, Barker RD (1996) Rapid least squares inversion of apparent resistivity pseudosections by a quasi-Newton method. Geophys Prospect 44:131-152

Loke MH, Acworth I, Dahlin T (2003) A comparison of smooth and blocky inversion methods in 2D electrical imaging surveys. Explor Geophys 34:182-187. doi:10.1071/EG03182

Loke MH, Chambers JE, Rucker DF, Kuras O, Wilkinson PB (2013) Recent developments in the direct-current geoelectrical imaging method. J Appl Geophys 95:135-156. doi:10.1016/j.jappgeo. 2013.02.017

Mieszkowski R, Dzierżek J, Stańczuk D (2014) Application of geoelectrical profiling in the delineation of shallow periglacial structures on the Drohiczyn Plateau. Studia Quaternaria 31:73-81. doi:10.2478/squa-2014-0007 
Myślińska E (1999) Parametry fizyczne torfów i ocena metod ich oznaczania [Physical properties of peats and evaluation of methods of their determination]. Przegląd Geologiczny 47:676-682 (in Polish with English summary)

Myślińska E (2001) Grunty organiczne i laboratoryjne metody ich badania, Wydawnictwo naukowe PWN, Warszawa, p 208 (in Polish)

Oświt J, Dembek W (1984) Ekspertyza przyrodniczo - łąkarska obiektu Całowanie - Podbiel. IMUZ, Zakład Przyrodniczych Podstaw Melioracji, Falenty (in Polish)

Pacanowski G, Czarniak P, Bąkowska A, Mieszkowski R, Welc F (2014) The role of geophysical ERT method to evaluate the leakproofness of diaphragm wall of deep foundation trenches on the example of the construction of retail and office complex in Lublin, Poland. Studia Quaternaria 31:91-99. doi:10.2478/squa2014-0009

Rydelek P (2011) Peatlands of Lubartów upland as the potential natural geological barriers. Biuletyn Państwowego Instytutu Geologicznego 446:407-416 (in Polish with English summary)

Rydelek P (2013) Origin and composition of mineral constituents of Fen Peats from Eastern Poland. J Plant Nutr 36:911-928

Rydelek P, Bąkowska A, Zawrzykraj P (2015) Variability of horizontal hydraulic conductivity of fen peats from Eastern Poland in relation to function of peatlands as a natural geological barriers. Geol Quart 59:426-432. doi:10.7306/gq.1180

Sarnacka Z (1964) Szczegółowa Mapa Geologiczna Polski w skali 1:50,000; arkusz Osieck (598). Wydawnictwa Geologiczne, Warszawa (in Polish)

Sarnacka Z (1968) Objaśnienia do Szczegółowej Mapy Geologicznej Polski 1: 50,000. Arkusz Osieck (598), Wydawnictwa Geologiczne (in Polish)
Sarnacka Z (1987) Evolution of the Vistula valley between the outlets of Radomka and Świder rivers in the Late Glacial and Holocene. Geogr Stud Special Issue no. 4:131-150

Schlumberger C, Schlumberger M, Leonardon EG (1933) A New contribution to subsurface studies by means of electrical measurements in drill holes. Am Inst Min Eng Tech Pub 503:1-18

Shemang EM, Molwalefhe LN (2009) DC resistivity and seismic refraction survey across the SE margin of Lake Ngami, NW Botswana. Acta Geophys 57:728-742. doi:10.2478/s11600-0090017-6

Slater LD, Reeve A (2002) Investigating peatland stratigraphy and hydrogeology using integrated electrical geophysics. Geophysics 67:365-378. doi:10.1190/1.1468597

Sumner JS (1976) Principles of induced polarization for geophysical exploration. Elsevier, Amsterdam

Telford WM, Geldart LP, Sheriff RE (1990) Applied geophysics, 2nd edn. Cambridge University Press, Cambridge, p 792

Von Post L (1922) Sveriges Geologiska Unders $\emptyset$ knings torvinentering och nogra av dess hittils vunna resultat (SGU peat inventory and some preliminary results). Svenska Mosskulturføreningens Tidskrft $36: 1-37$

Walter J, Hamann G, Lück E, Klingenfuss C, Zeitz J (2016) Stratigraphy and soil properties of fens: geophysical case studies from northeastern Germany. Catena 142:112-125. doi:10.1016/j. catena.2016.02.028

Waxman MH, Smith LJM (1968) Electrical conductivities in oilbearing shaly sand. Soc Pet J 8:107-122

Zogała B, Dubiel R, Zuberek WM, Rusin-Zogala M, Steininger M (2009) Geoelectrical investigation of oil contaminated soils in former underground fuel base: Borne Sulinowo, NW Poland. Environ Geol 58:1-9. doi:10.1007/s00254-008-1458-y 